\title{
Intelligent Controller based Maximum Power Point Tracking for Solar PV System
}

\author{
R.Ramaprabha \\ Assistant Professor \\ SSN College of Engineering \\ Rajiv Gandhi Salai, \\ Chennai, India
}

\author{
B.L. Mathur \\ Professor \\ SSN College of Engineering \\ Rajiv Gandhi Salai, \\ Chennai, India
}

\begin{abstract}
Solar photovoltaic system performance depends on environmental conditions. Solar photovoltaic panel is a power source having nonlinear internal resistance. As the intensity of light falling on the panel varies, its voltage as well as its internal resistance both varies. To extract maximum power from the panel, the load resistance should be equal to the internal resistance of the panel. This paper analyses the improved modelling of solar PV module and proposes a genetic algorithm (GA) based maximum power point tracking. The GA optimized values are used to train the artificial neural network (ANN). The MPPT is simulated and studied using MATLAB software.
\end{abstract}

\section{Keywords}

Solar PV system, MPPT, GA, ANN, MATLAB.

\section{Nomenclature}

\begin{tabular}{|c|c|c|}
\hline $\mathrm{I}_{\mathrm{PV}}, \mathrm{V}_{\mathrm{PV}}$ & - & Solar cell current and voltage \\
\hline $\mathrm{I}_{\mathrm{D}}, \mathrm{V}_{\mathrm{D}}$ & - & Diode current and voltage \\
\hline $\mathrm{I}_{\mathrm{ph}}$ & - & Light generated current \\
\hline G & - & Irradiance \\
\hline $\mathrm{T}$ & - & Temperature \\
\hline $\mathrm{n}$ & - & Diode ideality factor \\
\hline $\mathrm{k}$ & - & Boltzman's constant \\
\hline $\mathrm{q}$ & - & Electron charge \\
\hline $\mathrm{I}_{\mathrm{r}}$ & - & Reverse saturation current \\
\hline $\mathrm{R}_{\mathrm{sh},} \mathrm{R}_{\mathrm{se}}$ & - & Shunt and series resistance \\
\hline $\mathrm{V}_{\mathrm{t}}$ & - & Thermal voltage $(=\mathrm{nkT} / \mathrm{q})$ \\
\hline ref & - & $\begin{array}{l}\text { Second suffix represents all parameters at } \\
\text { reference condition }\left(\mathrm{G}=1000 \mathrm{~W} / \mathrm{m}^{2} \text { and }\right. \\
\left.\mathrm{T}=25^{\circ} \mathrm{C}\right)\end{array}$ \\
\hline $\mathrm{V}_{\mathrm{m}}, \mathrm{I}_{\mathrm{m}} \& \mathrm{P}_{\mathrm{m}}$ & - & $\begin{array}{l}\text { Maximum power point voltage, current \& } \\
\text { Power }\end{array}$ \\
\hline $\mathrm{N}_{\mathrm{S}} \& \mathrm{~N}_{\mathrm{P}}$ & - & Number of cells in series \& parallel \\
\hline
\end{tabular}

\section{INTRODUCTION}

The solar photovoltaic (SPV) system technologies have increasing roles in electric power technologies, providing more secure power sources and pollution-free electric supplies. A great deal of research has been conducted in this field over the last few decades. SPV panel is a power source having non linear internal resistance. The panel output power varies with temperature and insolation. It is desired to operate SPV panel at its maximum power point for economic reasons. To extract maximum power from the panel, its internal resistance should be equal to the load resistance. Chopper circuit is interposed between SPV and the load resistance to adjust the load resistance seen by SPV equal to its internal resistance by varying the duty cycle of the chopper. Many number of algorithms available for the MPPT including perturb and observe, incremental conductance, parasitic capacitance, constant voltage and fuzzy logic algorithms [1][4].These methods have disadvantages like costly, difficult to implement and non-stable. For this purpose ANN comes with a solution. ANN is suitable to handle non-linearity, uncertainties and parameter variations in a controlled environment. Hence many number of ANN algorithms have been developed for this purpose [5]-[9].

The purpose of this paper is to develop ANN based MPP tracking scheme for SPV system with varying environmental conditions. In section 3 improved modelling of SPV is described. In the subsequent sections the proposed MPPT scheme is explained. The complete system is simulated using MATLAB-SIMULINK and the results are presented.

\section{SOLAR PV ARRAY MODELLING}

The standard five parameter model of SPV module is shown in Figure 1. Improved model equations (1) to (8) are used to model SPV cell in I quadrant [10]-[13].

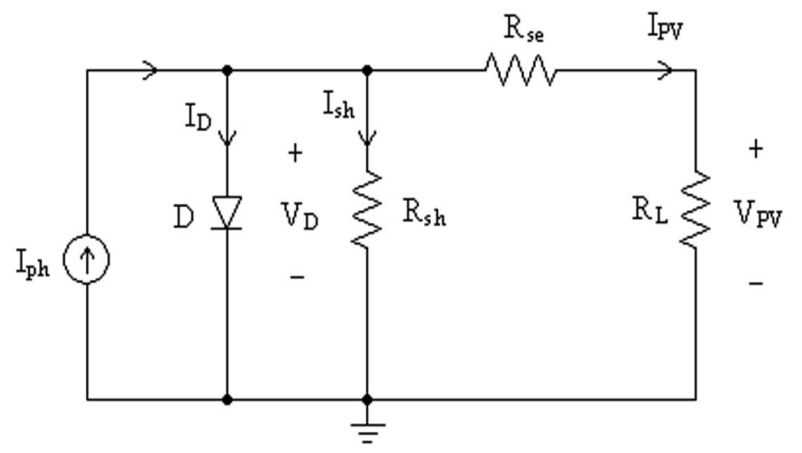

Figure 1 . Electrical equivalent circuit model of a SPV module

$I_{P V}=I_{p h}-I_{r}\left[\exp \left\{\frac{V_{P V}+I_{P V} R_{s e}}{V_{t}}\right\}-1\right]-\frac{\left(V_{P V}+I_{P V} R_{s e}\right)}{R_{s h}}$ 
Where

$$
\begin{aligned}
& I_{p h}=\left\{I_{p h, r e f}\left[1+\alpha\left(T-T_{r e f}\right)\right]\right\} \frac{G}{G_{r e f}} \text { and } I_{p h, r e f}=I_{s c, r e f} \\
& \text { and } \quad I_{\text {phref }}=\frac{R_{s h}+R_{s e}}{R_{s h}} \times I_{s c r e f} \\
& I_{r}=\frac{I_{s c, r e f}+\alpha\left(T-T_{r e f}\right)}{\exp \frac{V_{o c, r e f}+\beta\left(T-T_{r e f}\right)}{n V_{t}}-1} \text { and } \\
& I_{r, r e f}=\frac{I_{s c, r e f}}{\exp \left(\frac{V_{o c, r e f}}{V_{t, r e f}}\right)-1} \\
& V_{t}=V_{\text {tref }} \frac{T}{T_{r e f}} \text { and } V_{\text {tref }}=\frac{n_{r e f} k T_{r e f}}{q} \\
& R_{s h}=\frac{2.6}{G-0.086} \quad \text { (obtained by curve fitting) } \\
& I_{m}=I_{m r e f} \times G \text { and } V_{m}=V_{m r e f}+\left\{\beta\left(T-T_{r e f}\right)\right\} \\
& R_{\text {se }} \frac{G}{G_{\text {ref }}}=\frac{V_{\text {terf }}}{I_{\text {rref }}} \exp \left[-\frac{V_{\text {mref }}+I_{\text {mref }} R_{\text {seref }}}{V_{\text {tref }}}\right] \\
& +R_{\text {seref }}-\frac{G}{G_{r e f}}\left(\frac{V_{t}}{I_{r}} \exp \left[-\frac{V_{m}+I_{m} R_{s e}}{V_{t}}\right]+R_{s e}\right) \\
& n=n_{r e f} \frac{T}{T_{r e f}}
\end{aligned}
$$

Practical SPV cell is represented by (1). Here the five parameters are $I_{p h}, I_{r}, V_{t}, R_{s e}$ and $R_{s h}$. It can be shown that the array parameters for series array consist of $\mathrm{N}_{\mathrm{S}}$ cells in series:

$I_{\text {ph,array }}=I_{\text {ph }}, \quad I_{r, \text { array }}=I_{r}, V_{t, \text { array }}=N_{S} V_{t}, \quad R_{\text {se,array }}=N_{S} R_{\text {se }} \quad$ and $\mathrm{R}_{\text {sh,array }}=\mathrm{N}_{S} \mathrm{R}_{\text {sh }}$. For parallel array consists of $\mathrm{N}_{\mathrm{P}}$ cells in parallel: $\mathrm{I}_{\text {ph,array }}=\mathrm{N}_{\mathrm{P}} \mathrm{I}_{\mathrm{ph}}, \quad \mathrm{I}_{\mathrm{r}}=\mathrm{N}_{\mathrm{P}} \mathrm{I}_{\mathrm{r}}, \quad \mathrm{V}_{\mathrm{t} \text {,array }}=\mathrm{V}_{\mathrm{t}}, \quad \mathrm{R}_{\text {se,array }}=\mathrm{R}_{\mathrm{se}} / \mathrm{N}_{\mathrm{P}} \quad$ and $\mathrm{R}_{\text {ph,array }}=\mathrm{R}_{\mathrm{ph}} / \mathrm{N}_{\mathrm{S}}$.

The simulation results are shown in Figure 2. The comparison of the model parameters with manufacturer's datasheet (SOLKAR module) is given in Table 1 .

To validate the model, at five important points the values have been checked [14]. From Figure 3 and Figure 4, it is clear that the proposed model equations very well reproduce the practical characteristics.
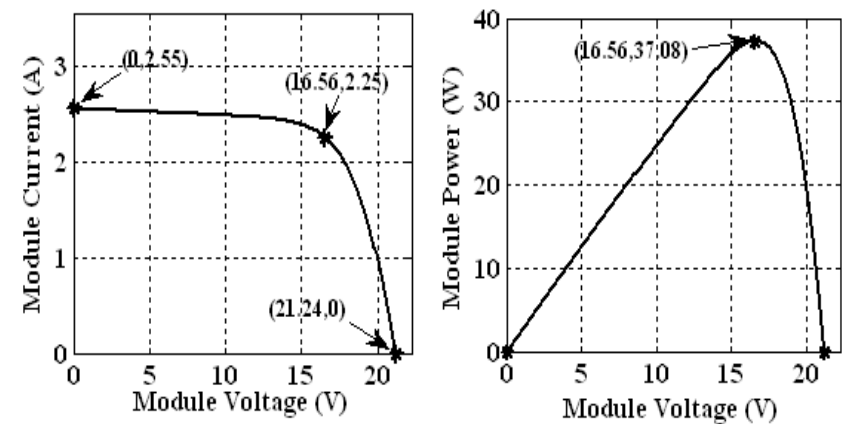

Figure 2. SOLKAR SPV module adjusted characteristics

Table 1. Comparison of Parameters of the Adjusted Model and SOLKAR Datasheet Values at Reference Conditions

\begin{tabular}{|c|l|c|c|}
\hline $\begin{array}{c}\text { S. } \\
\text { No. }\end{array}$ & \multicolumn{1}{|c|}{ Parameters } & Model & Datasheet \\
\hline 1 & Maximum Power $\left(\mathrm{P}_{\mathrm{m}}\right)$ & $37.08 \mathrm{~W}$ & $37.08 \mathrm{~W}$ \\
\hline 2 & Voltage at Maximum power $\left(\mathrm{V}_{\mathrm{m}}\right)$ & $16.56 \mathrm{~V}$ & $16.56 \mathrm{~V}$ \\
\hline 3 & Current at Maximum power $\left(\mathrm{I}_{\mathrm{m}}\right)$ & $2.25 \mathrm{~A}$ & $2.25 \mathrm{~A}$ \\
\hline 4 & Open circuit voltage $\left(\mathrm{V}_{\mathrm{oc}}\right)$ & $21.24 \mathrm{~V}$ & $21.24 \mathrm{~V}$ \\
\hline 5 & Short circuit current $\left(\mathrm{I}_{\mathrm{sc}}\right)$ & $2.55 \mathrm{~A}$ & $2.55 \mathrm{~A}$ \\
\hline 6 & No. of Series Cells $\left(\mathrm{N}_{\mathrm{s}}\right)$ & 36 & 36 \\
\hline 7 & Series resistance, $\mathrm{R}_{\mathrm{se}}$ & $0.47 \Omega$ & \\
\hline 8 & Shunt resistance, $\mathrm{R}_{\mathrm{sh}}$ & $145.62 \Omega$ & \\
\hline 9 & Ideality Factor, $\mathrm{n}$ & 1.5 & \\
\hline
\end{tabular}
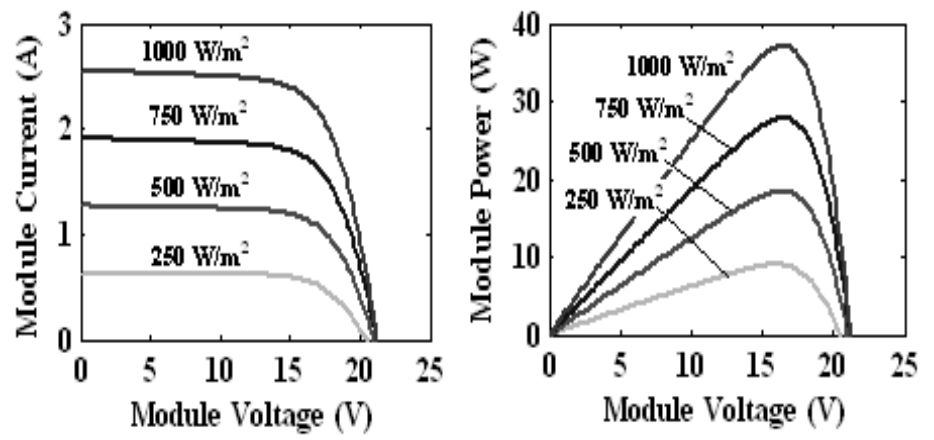

Figure 3. Model Characteristics of SOLKAR solar module at different insolations $\left(\mathrm{T}=\mathbf{2 5}^{\circ} \mathrm{C}\right)$ 

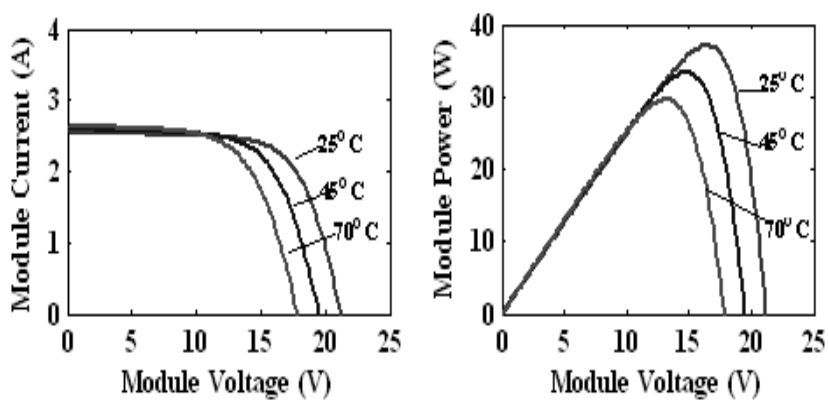

Figure 4. Model Characteristics of SOLKAR solar module at different Temperatures $\left(G=1000 \mathrm{~W} / \mathrm{m}^{2}\right)$

\section{FEED}

FORWARD

NEURAL

\section{NETWORKS}

Artificial neural networks are best suited for the approximation of non-linear systems.Non-linear systems can be exactly emulated by multilevel neural networks. They give best results than other algorithms.Neural networks contain three layers namely input layer,hidden layer,output layer.Feed-forward is the simple type of neural networks.In this type the information moves in only forward direction, input nodes to hidden nodes and to output nodes. There are no cycles or loops in this network. The block diagram of the ANN for producing maximum voltage and power for given $G$ and $T$ is shown in Figure 5. The neural network used here has two input layers,hidden layers and two output layers and back propagation trainig method is used.

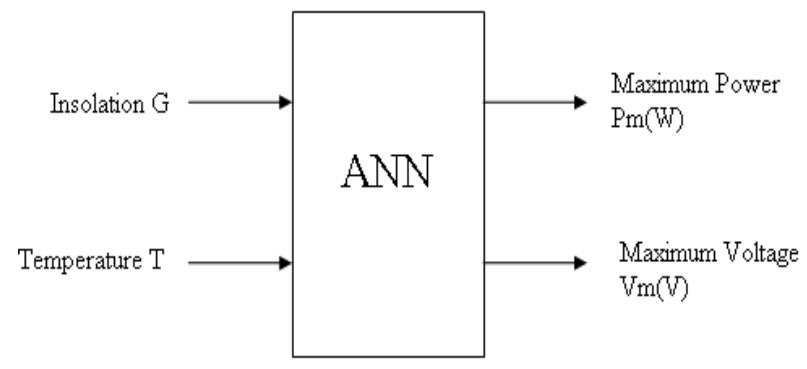

Figure 5. Block diagram of ANN Block

\section{THE PROPOSED MPPT SCHEME}

The block diagram of the proposed MPPT scheme is shown in the Figure 6. In this scheme ANN is used to find out the maximum voltage. The ANN is trained by a set of input and output data which are optimized using genetic algorithm (GA) . GA is based on natural genetics [15]. They draw their search power from the natural 'law' of survival of the fittest. The GA repeatedly modifies a population of individual solutions. At each step, the GA selects individuals randomly from the current population to be parents and uses them to produce the children for the next generation. Over successive generations, the population evolves toward an optimal solution. The GA uses three main types of rules at each step to create the next generation from the current population:

- Selection rules that select the individuals, called parents and contribute to the population at the next generation.

- Crossover rules that combine two parents to form children for the next generation.
- Mutation rules that apply random changes to individual parents to form children.

The steps involved in creating and implementing a GA are as follows:

- Generate an initial, random population of individuals for a fixed size.

- Evaluate their fitness to minimize integral square error.

- Select the fittest members of the population.

- Reproduce using a probabilistic method (e.g., roulette wheel).

- Implement crossover operation on the reproduced chromosomes.

- Execute mutation operation with low probability.

- Repeat Step 2 until a predefined convergence criterion is met.

The structure of the proposed neural network is shown in Figure 7.The training results of ANN is shown in Figure 8. The voltage is compared with the SPV Array voltage and the error is given to the PI controller. PI controller is used with ANN block to reduce the steady state error. This PI controller is tuned using ZieglerNichols tuning method. The output of the PI controller is compared with high frequency triangular wave.And this pulse is given to the boost converter circuit to change the output of the system. The simulink model of the proposed MPPT scheme is shown in Figure 9.

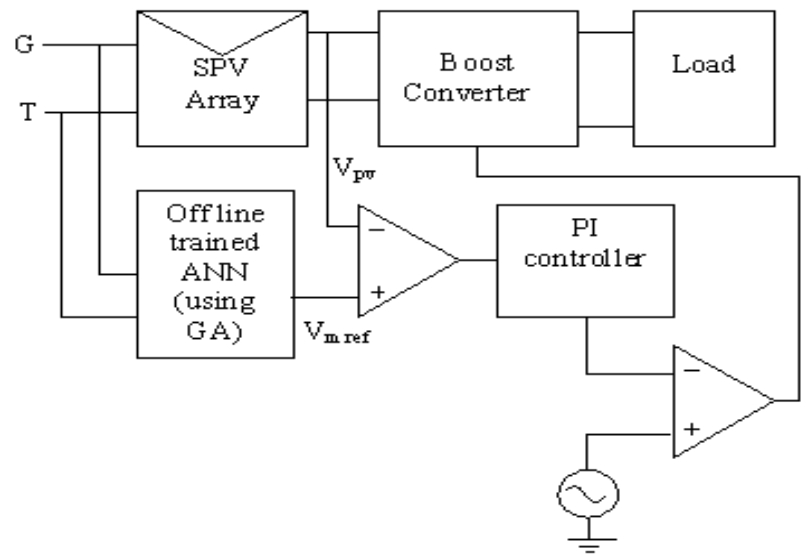

Figure 6. Proposed MPPT Scheme

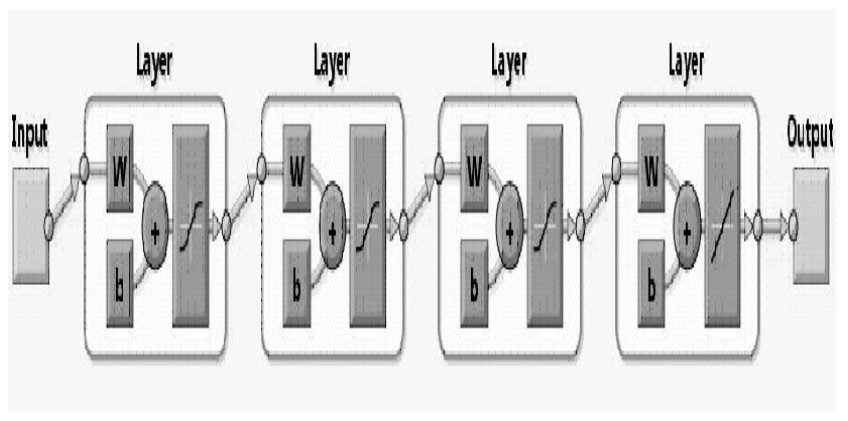

Figure 7. Feed Forward Neural Network for MPPT 


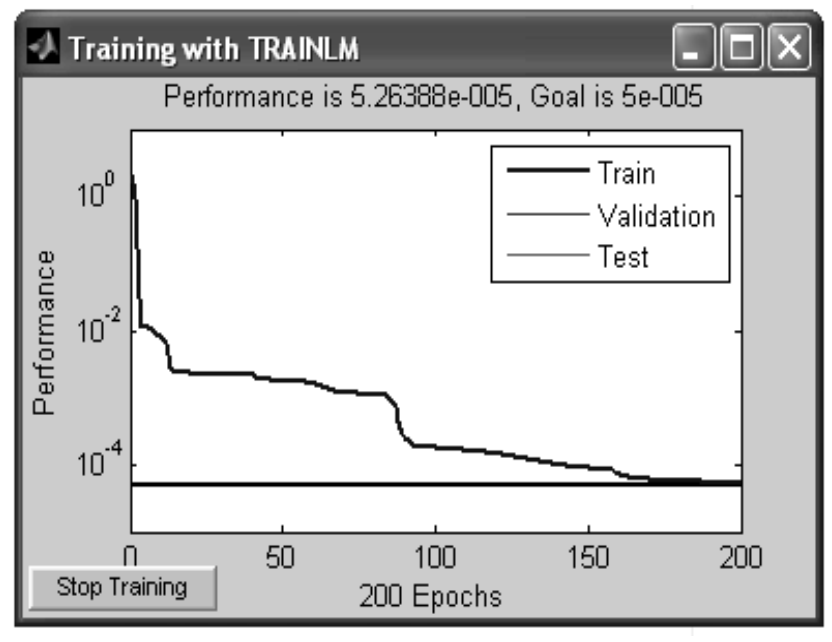

Figure 8. Training Results of ANN Block
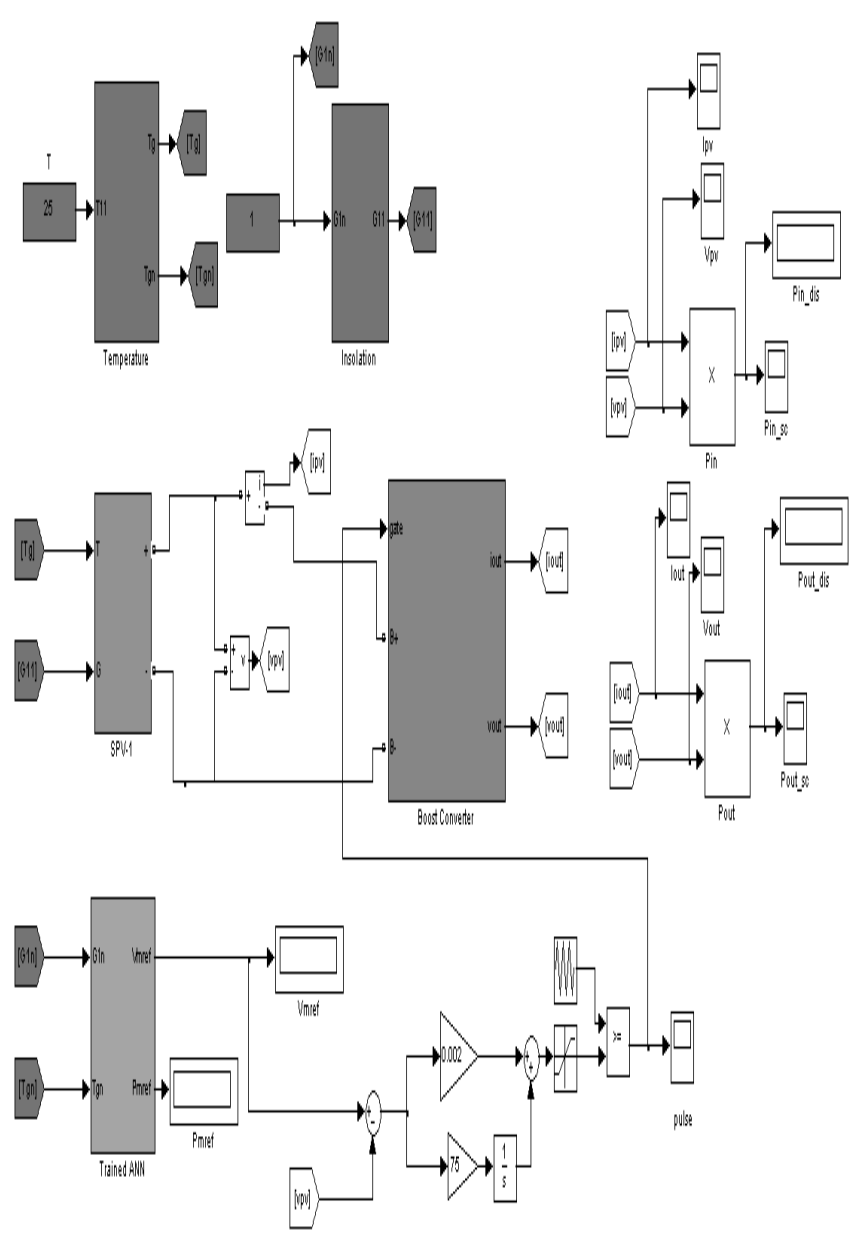

Figure 9. Simulink Block Diagram

The simulated output waveforms for two different insolation levels and temperatures are shown in Figure 10 and Figure 11. The result is obtained by training the ANN with 250 data points.
Table 2 shows the comparison between trained and expected values.
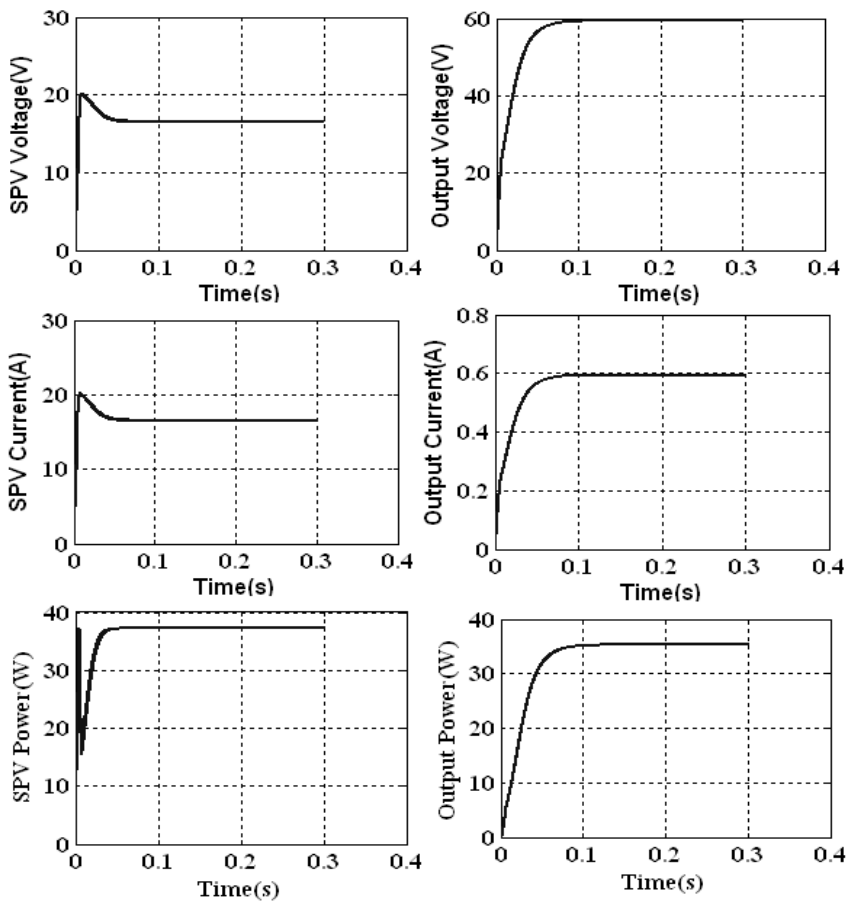

Figure 10. Simulation output for $G=1000 \mathrm{~W} / \mathrm{m}^{2}, T=25^{\circ} \mathrm{C}$
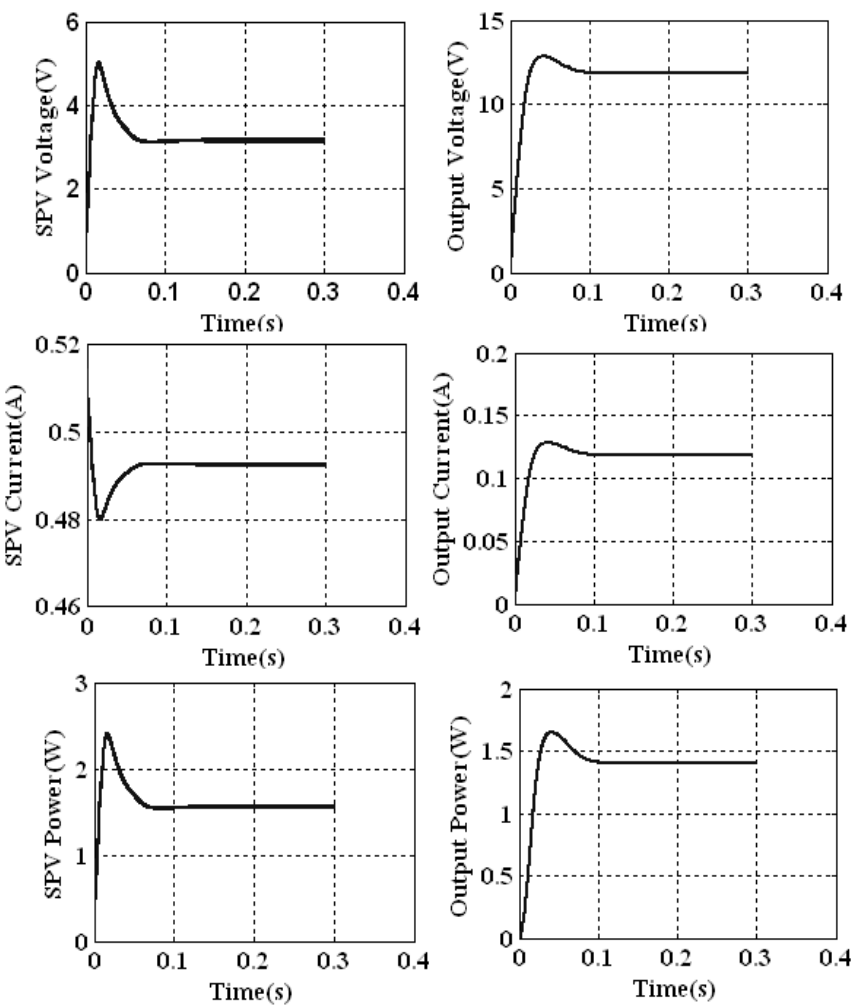

Figure 11. Simulation output for $G=200 \mathrm{~W} / \mathrm{m}^{2}, T=31.9^{0} \mathrm{C}$ 
TABLE 2. Comparison between Trained and Simulated Values of Output Power

\begin{tabular}{|c|c|c|c|c|}
\hline \multirow{2}{*}{$\begin{array}{c}\text { Insol } \\
\text {-ation } \\
\mathbf{G} \\
\left(\mathbf{W} / \mathbf{m}^{2}\right)\end{array}$} & \multirow{2}{*}{$\begin{array}{c}\text { Temper- } \\
\text { ature } \\
\mathbf{T}\left({ }^{0} \mathrm{C}\right)\end{array}$} & \multicolumn{2}{|c|}{$P_{\max }(W)$} & \multirow{2}{*}{$\begin{array}{c}\text { Error } \\
\text { Percentage } \\
(|\mathbf{A}-\mathbf{B}| / \mathbf{B})^{*} \mathbf{1 0 0}\end{array}$} \\
\hline & & $\begin{array}{c}\text { Trained } \\
\text { Value (A) }\end{array}$ & $\begin{array}{l}\text { Expected } \\
\text { Value (B) }\end{array}$ & \\
\hline 1000 & 25 & 37.06 & 37.08 & 0.05 \\
\hline 800 & 38.0 & 24.50 & 24.48 & 0.08 \\
\hline 600 & 35.9 & 13.87 & 13.80 & 0.51 \\
\hline 400 & 33.9 & 5.01 & 4.95 & 1.21 \\
\hline 200 & 31.9 & 1.98 & 1.91 & 3.66 \\
\hline 100 & 31.04 & 1.87 & 1.79 & 4.46 \\
\hline
\end{tabular}

\section{CONCLUSION}

In this paper improved modelling of SPV array has been presented. To extract the maximum power from the SPV source GA is used. The optimized values of power and the corresponding voltage values for different insolation and temperature have been used for training the ANN. The GA based offline trained ANN is then used as the means for providing reference voltage corresponding to maximum power for any environmental changes. For different conditions the proposed algorithm has been verified and it is found that the error percentage lies between $0.05 \%$ to $4.46 \%$. This error can be reduced by increasing the number of the training data for ANN. Moreover PI controller also can be optimized to improve the results.

\section{ACKNOWLEDGMENTS}

The authors wish to thank the management of SSN college of Engineering, Chennai for providing all the computational facilities to carry out this work.

\section{REFERENCES}

[1] C. Hua and C. Shen, "Comparative Study of Peak Power Tracking Techniques for solar Storage System", IEEE Applied Power Electronics Conference and Exposition Proceedings, Vo1.2, pp.679- 683, 1988.

[2] K.H.Hussein, I. Muta, T. Hoshino and M. Osakada, "Maximum Photovoltaic Power Tracking: An Algorithm for Rapidly Changing Atmospheric Conditions," IEE Proceedings on Generation, Transmission and Distribution, Vol.142, No.1, pp.59-64, January 1995.

[3] Brambilla, 'liew Approach U1 Photovoltaic Arrays Maximum Power Point Tracking", Proceedings of 35th IEEE Power Electronics Specialists Conference, vol. 2, G. 632-637., 1998.

[4] D.P. $\mathrm{H} \mathrm{u} \mathrm{h}$ and M.E. Ropp, "Comparative Study of Maximum Power Point tacking Algorithm Using an Experimental, Programmable, Maximum Power Point
Tracking Test Bed", Proceedings of 28th IEEE Photovoltaic Specialists Conference, pp. 1699-1702, 2000.

[5] T. Hiyama and K. Kitabayashi, "Neural Network Based Estimation of Maximum Power Generation from PV Module Using Environment Information", IEEE Transactiom on Energy, Conversion, Vol. 12, NO. 3, pp.241-247, September 1997.

[6] T. Hiyama, S. Kouzuma, T. Imakubo, and T.H. Ortmeyer, "Evaluation of Neural Network Based Real Time Maximum Power Tracking Controller Far PV System", IEEE Transaction On Energv Conversion, Vol.10, No3,pp.543548, Sept. 1995

[7] T. Hiyama, S. Kauuma, and T. Imakubo ,"Identification Of Optimal Operating Point Of PV Modules Using Neural Network for Real Time Maximum Power Tracking Control", IEEE Transaction on Energv Conversion, Vol.10, No. 2, pp. 360-367, June 1995.

[8] A. de Medeiros Torres, F.L.M. Antunes, and F.S. dos Reis, "An Artificial Neural Network-Based Real Time Maximum Power Tracking Controller For Connecting a PV System to the Grid", Proceeding of IEEE the 24th Annual Conference on Industrial Electronics Society , Vol. 1 , pp. $554-558$, 1998.

[9] A. AI-Amoudi and L. Zhang, "Application of Radial Basis Function Networks For Solar-Array Modelling And Maximum Power-Point Prediction", IEE Proceeding Generation, Transmission and Distribution, Vol. 147, No. 5,pp. 310-316,Sept. 2000.

[10] R.Ramaprabha and Dr.B.L.Mathur,"A Technique to extract maximum Power from Photovoltaic Panels",Proc. of IEEE Int. Conf. on Recent Advancements and Applications of Computer in Electrical Engineering, pp. 447 -449, Bikaner, Rajastan, India, Mar. 24-25, 2007

[11] S Geoff Walker, "Evaluating MPPT Converter Topologies using a MATLAB PV Model”.

[12] .Duffie.J.A, and Beckman.W.A.(2006), Solar Engineering of Thermal Processes. John Wiley Sons, $3^{\text {rd }}$ edition.

[13] Marcelo Gradella Villalva, Jonas Rafael Gazoli and Ernesto Ruppert Filho (2009),"Comprehensive Approach to Modeling and Simulation of Photovoltaic Arrays",IEEE Transactions On Power Electronics,Vol.24, No.5,pp 1198-1208.

[14] Engin Karatepe, Mutlu Boztepe and Metin Colak, "Development of suitable model for characterizing photovoltaic arrays with shaded solar cells", Solar Energy, 2007, pp 329-340.

[15] Goldberg, D.E. , "Genetic Algorithms in Search, Optimization and Machine Learning", Addison-Wesley, Reading, Massachusetts, Harlow, England, 1989. 